\title{
Variation of Three Co-occurring Taxa of the Genus Cyathea in Singharaja and Kanneliya Lowland Rain Forests of Sri Lanka
}

\author{
R.H.G. Ranil, D.K.N.G. Pushpakumara ${ }^{1}$, S. Samita ${ }^{1}$ \\ D.S.A. Wijesundara ${ }^{2}$ and D.U.M.B. Dhanasekara ${ }^{2}$ \\ Postgraduate Institute of Agriculture \\ University of Peradeniya \\ Peradeniya, Sri Lanka
}

\begin{abstract}
The objective of this study was to identify variation of three co-occurring taxa of the genus Cyathea at Singharaja and Kannelliya forests. Fifty three mature individuals were sampled from both forests for morphological variation, reproductive biology and cytological investigations. Twenty five morphological characters were initially assessed and data were analyzed for 10 characters by principal component analysis (PCA) and cluster analysis. Based on these, three taxa studied were identified as Cyathea sinuata Hook. \& Grev., Cyathea hookeri Thw. and the hybrid between the two parents. Both parents and the hybrid were cytologically similar with meiotic chromosomes of $n=69$. Reproductive biology of the three taxa were similar in terms of spore germination, gametophyte and sex organ development. However, the hybrid did not produce the sporophyte indicating it may be sterile.
\end{abstract}

\section{INTRODUCTION}

The family Cyatheaceae is one of the most interesting families among Pteridophytes, due to its wide geographical distribution combined with pronounced local endemism (Tryon and Gastony, 1975). The family consists of about 500 scaly tree fern species worldwide with diversity centers in tropical wet mountain regions (Tryon and Gastony, 1975; Conant et al., 1996). In Sri Lanka, the family is represented by a single genus, Cyathea, which includes eight taxa (six species, one variety and one suspected hybrid) (Holttum, 1965; Sledge, 1982; Philcox, 2006; Ranil et al., 2009a; 2009b), of which, 75\% are endemic to the island (Ranil et al., 2009b). Although Holltum (1965; 1981) suggested that Sri Lankan tree ferns have phytogeographical affinities with African elements, especially in East Africa, Madagascar, Mascarene and Seychelles, recently Janssen et al., (2008) have shown that Sri Lankan tree ferns form a monophyletic group and not closely related to African tree ferns. Among the tree ferns, three taxa are co-occurring in Singharaja and Kannelliya forests of Sri Lanka, including the world's only simple leaved tree fern Cyathea sinuata Hook. \& Grev. (Kramer, 1990 ) with a wide range of morphological variation. $C$. sinuata is closely allied with $C$. hookeri Thw (Holltum, 1981). In addition, an intermediate type to both species has also been reported (Sledge, 1982; Ranil et al., 2004) and proposed as a suspected natural hybrid. However, Philcox (2006) has recently excluded this suspected hybrid from Flora of Ceylon (Volume 15). Even though, flowering plants and fauna in Sri Lanka have been studied extensively

1 Department of Crop Science, Faculty of Agriculture, University of Peradeniya, Peradeniya, Sri Lanka

2 Department of National Botanic Gardens, Peradeniya, Sri Lanka 
[Bambaradeniya, (2006); Dassanayake and Fosberg (1980-1991); Dassanayeke et al., (19941995); Dassanayake and Clayton (1996-1999); IUCN, (2007); MFE, (1999); NSF, (2000)], information on Pteridophytes, particularly tree ferns is scanty, which is a major impediment for conservation and sustainable use of such plant categories. Thus, the objective of this study was to identify variation of morphological characters and reproductive biology and cytology of three co-occurring taxa of the genus Cyathea in Kanneliya and Singharaja forests.

\section{MATERIALS AND METHODS}

\section{Identification of morphological variation}

Twenty five morphological characters (Annexure I) were recorded in the field from a total of 53 mature individuals of three taxa. Sample size of each taxon and their relative population density in Singharaja and Kanneliya forests are given in Table 1.

Table 1. Sample sizes of the three taxa and their relative population densities in Singharaja and Kanneliya forests.

\begin{tabular}{ccccc}
\hline \multirow{2}{*}{ Taxon } & \multicolumn{2}{c}{ Singharaja } & \multicolumn{2}{c}{ Kanneliya } \\
\cline { 2 - 5 } & Sample size & $\begin{array}{c}\text { Population } \\
\text { density }\end{array}$ & Sample size & $\begin{array}{c}\text { Population } \\
\text { density }\end{array}$ \\
\hline 1 & 25 & Common & 12 & Common \\
2 & 7 & Limited & 5 & Limited \\
3 & 2 & Rare & 2 & Rare \\
\hline Total & 34 & & 19 & \\
\hline
\end{tabular}

In addition, the deposited specimens at the National Herbarium and scanned images of similar taxa at the Kew Herbarium were also examined for comparison purposes. Specimens were also collected for further observation and to be deposited at the National Herbarium. Out of 25 characters from which data were collected it was found that with respect to 15 characters, individual plants did not vary. Therefore, only 10 characters were selected for the final analysis (Annexure I). Data were subjected to principal component (PCA) and cluster analysis using SAS (1999).

\section{Reproductive biology}

Spores were collected from fertile fronds from each taxon from Kanneliya and Singharaja forests, stored and germinated according to the protocol developed by Ranil et al., (2008). Fifteen culture plates of each taxon were maintained under fluorescent illumination of 1000 1500 lux at 12 hours per day. The temperature of the culture environment was $22-28{ }^{\circ} \mathrm{C}$ and 14-18 ${ }^{\circ} \mathrm{C}$ during day and night times, respectively. In each culture plate, the number of spores sown and the number of spores germinated were counted per unit area using a transparent grid. Five randomly selected grids $\left(1 \mathrm{~cm}^{2}\right)$ were used for counting spores in each culture plate. At the different development stages of gametophytes, the number of cells in gametophytes were counted and width of gametophytes was measured at mature stage to identify all development stages. All observations were made using a light microscope (x4, $\mathrm{x} 10, \mathrm{x} 100$ and x1000) and photographed using a digital camera. After sex organs developed, 30 individuals of bisexual gametophytes from each taxon were transferred to 90 Petri dishes 
prepared with filter paper wetted with Albert solution to observe the development of sporophytes. After observing the first frond, individual gametophytes were transferred to humus-rich potting media (1:1:2 of sand: top soil: compost) for further observations.

\section{Cytological investigation}

Immature spores of various stages were collected in the early morning (7.00-8.00 am) from each taxa from both forests. Immediately after collection, spores were stored in pre-prepared Carnoy's fluid in the field (acetone: chloroform: glacial acetic acid; 3:2:1). Spores were then transferred to the laboratory and stored in $70 \%$ ethanol in a refrigerator at $-4{ }^{0} \mathrm{C}$. Acetocarmine squash techniques were followed for both meotic and mitotic chromosome studies (Manton and Sledge, 1954). Sporangia were removed from sori using a needle and put on two drops of Acetocarmine solution on a slide. Sporangia were squashed using a glass rod and mixed well. Remaining debris was washed out by adding a few drops of Acetocarmine. Then, it was covered using a cover slip and heated gently to remove air bubbles. Cytological observation was made using a light microscope (x 1000) and photographed using a digital camera. Number of chromosomes was directly observed and counted.

\section{RESULTS AND DISCUSSION}

\section{Morphological variation}

Results from the principal component analysis revealed that the first two principal components explained $84 \%$ of the cumulative variation of three taxa (Table 2). Eigen values of the other PCs are very small in relation to the first two PCs, which indicates that only two dimensions (or aspects) are adequate to explain the data. In addition, eigen values of the 2 PCs being equal suggest that the two aspects are equally important. These facts clearly suggest that further analysis can be performed based on PC 1 and PC 2. Important characters included in each principal component, based on Eigen vectors are given in Table 3. Fig. 1 shows grouping of 53 individuals of the three taxa based on Principal Components 1 and 2 while Fig. 2 shows the dendrogram obtained from cluster analysis. Variation of major taxonomic characters of the three taxa is given in Table 4.

Table 2. Eigen value of correlation matrix of principal components.

\begin{tabular}{cccc}
\hline $\begin{array}{c}\text { Principal } \\
\text { Component }\end{array}$ & Eigen values & Proportion & Cumulative value \\
\hline $\mathbf{1}$ & $\mathbf{4 . 8 2 0 0}$ & $\mathbf{0 . 4 3 8 2}$ & $\mathbf{0 . 4 3 8 2}$ \\
$\mathbf{2}$ & $\mathbf{4 . 4 2 5 6}$ & $\mathbf{0 . 4 0 2 3}$ & $\mathbf{0 . 8 4 0 5}$ \\
3 & 0.9653 & 0.0878 & 0.9283 \\
4 & 0.4102 & 0.0373 & 0.9656 \\
5 & 0.1352 & 0.0123 & 0.9779 \\
6 & 0.0939 & 0.0085 & 0.9864 \\
7 & 0.0739 & 0.0067 & 0.9931 \\
8 & 0.0442 & 0.0040 & 0.9971 \\
9 & 0.0283 & 0.0026 & 0.9997 \\
10 & 0.0030 & 0.0003 & 1.0000 \\
\hline
\end{tabular}


According to results of PCA (Fig. 1), dendrogram (Fig. 2) and also based on taxonomic characters (Table 4), taxon 1 is represented by $C$. sinuata (Plate $1 \mathrm{~A}_{1}, \mathrm{~A}_{2}$ ), whereas taxon 2 resembles $C$. hookeri (Plate 1B). Taxon 3 shows intermediate status of $C$. sinuata and $C$. hookeri in majority of characters (Plate 1C) (Table 4). However, with respect to some vegetative characters, it was closer to $C$. sinuata than $C$. hookeri. Taxon 3 was highly deviated from both parents due to their pinnetified leaf, forked vein, number of vein pairs and sori. All mature individuals of taxon 3 were recorded in the vicinity of $C$. sinuata and $C$. hookeri. Immature individuals of taxon 3 were not recorded in close proximity to its mature individuals from both forests. Based on these observations, it is proposed that taxon 3 resembles a suspected natural hybrid between $C$. sinuata and $C$. hookeri.

Table 3. Eigen vector for first two principal components of the 10 morphological characters

\begin{tabular}{lcc}
\hline Character & PC 1 & PC 2 \\
\hline 1. Stem diameter & $\mathbf{0 . 4 2 7}$ & -0.100 \\
2. Leaf type & $\mathbf{0 . 4 4 1}$ & 0.020 \\
3. Margin of base & $\mathbf{0 . 4 2 8}$ & 0.116 \\
4. Leaf margin & $\mathbf{0 . 4 3 3}$ & 0.115 \\
5. Margin of leaf tip & $\mathbf{0 . 2 0 3}$ & 0.171 \\
6. Veinlets & 0.014 & $\mathbf{0 . 4 2 6}$ \\
7. Number of veinlets in single cluster (pairs) & 0.007 & $\mathbf{0 . 4 5 2}$ \\
8. Position of sori & 0.014 & $\mathbf{0 . 4 2 6}$ \\
9. Average number of sori in single cluster (pairs) & -0.089 & $\mathbf{0 . 4 1 5}$ \\
10. Sori arrangement & -0.134 & $\mathbf{0 . 4 3 6}$ \\
\hline
\end{tabular}

It is clear from the dendrogram that $C$. sinuata is further clustered into two sub groups $\left(\mathrm{A}_{1}\right.$ and $A_{2}$ ) on the basis of leaf margin, number of veinlets, sori arrangement and number of pairs of sori (Plate 1: $A_{1}, A_{2}$ ). Such characters alone are not strong enough to classify those as varieties or sub species of $C$. sinuata. It can be best described at this stage as two morphotypes of $C$. sinuata.

\section{Reproductive biology of parents and hybrid}

Details of spore germination, gametophyte and sporophyte development of the three taxa are given in Table 5. Accordingly, time taken to spore germination, time taken to gametophyte development, initiation of sex organs in gametophyte are similar in the three taxa studied (Table 5). Even though the suspected hybrid showed relatively higher spore germination rate $(39 \pm 7.33)$, it did not show any sign of sporophyte development (Table 5 and Plate 2). Only $C$. sinuata and $C$. hookeri produced successful sporophytes. Conant (1990) in a study conducted on Alsophylla bryophila (Syn: C. bryophila), A. portoricensis (C. portoricensis) in Cuba found that the germination percentage of hybrid is less $(29 \%)$ than that of both parents $(50 \%$ and $36 \%)$. He also noted development of only a few sporophytes from the hybrid spores.

Hybrids share the genetic materials from two different species. They may develop new characters and sometimes they may be isolated reproductively from their parent populations. As Strahler and Strahler (2005) suggested, this may lead to sympatric speciation. The family Cyatheaceae is interesting because it has been hypothesized that tree ferns form new species by an autogamous allohomoploidy (Conant and Cooper-Driver, 1980). 
Ranil et al.

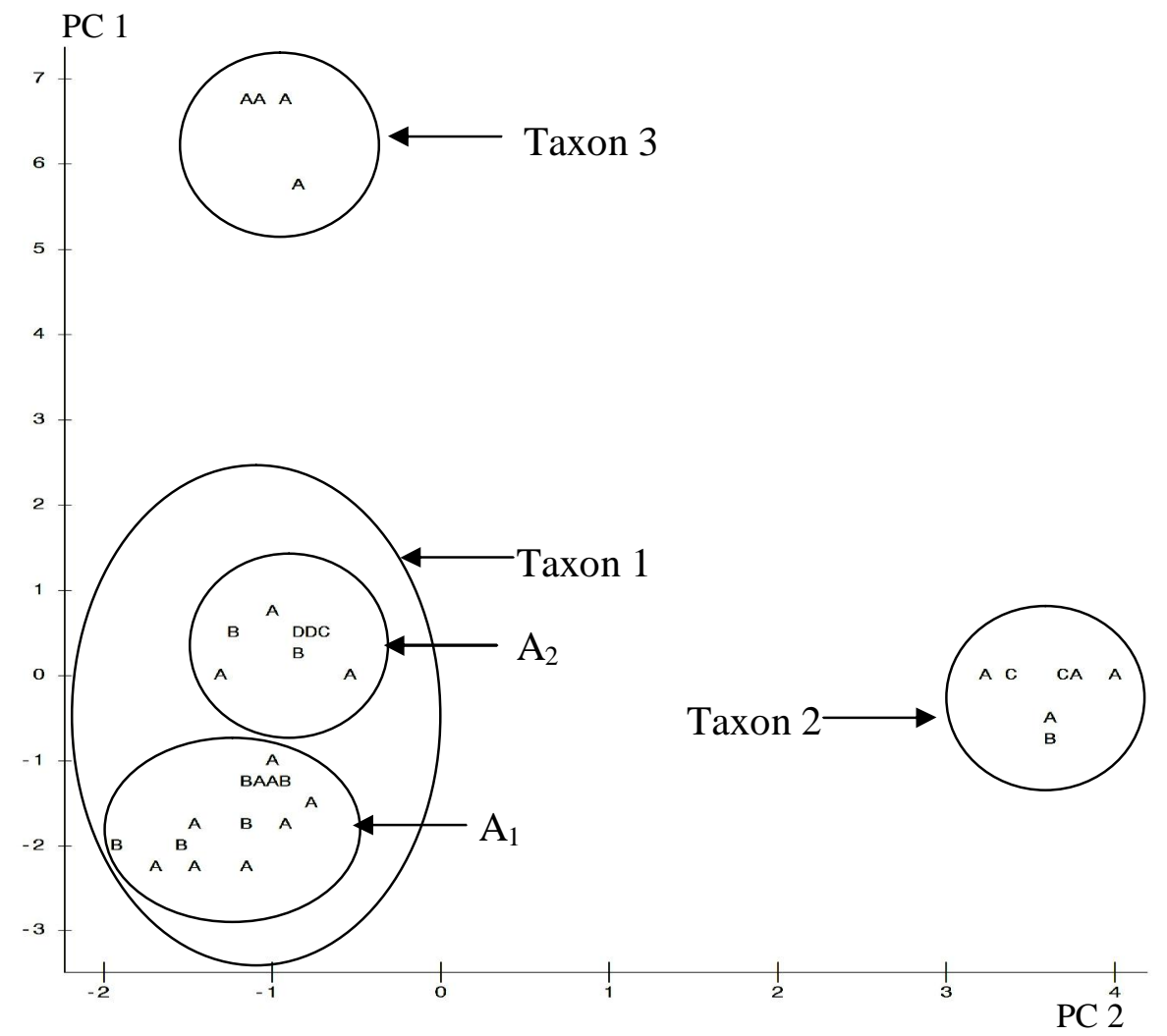

Fig. 1. Clustering of 53 individuals based on principal components 1 and 2.

[Note: A denotes one individual, $B$ denotes two individuals etc. $A_{1}$ and $A_{2}$ are two morpho-types of Cyathea sinuata].

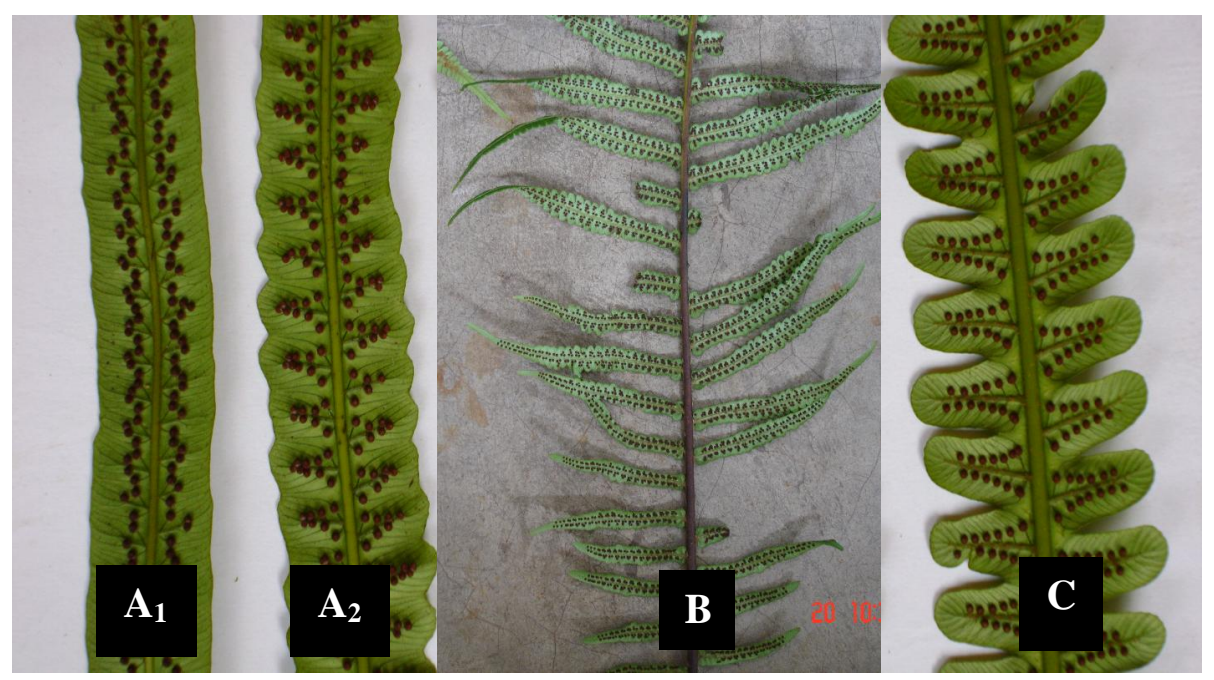

Plate 1. Variation of leaf morphology of C. sinuata $\left(A_{1} \& A_{2}\right)$, C. hookeri $(B)$ and C. sinuata $\times$ C. hookeri $(\mathbf{C})$. 


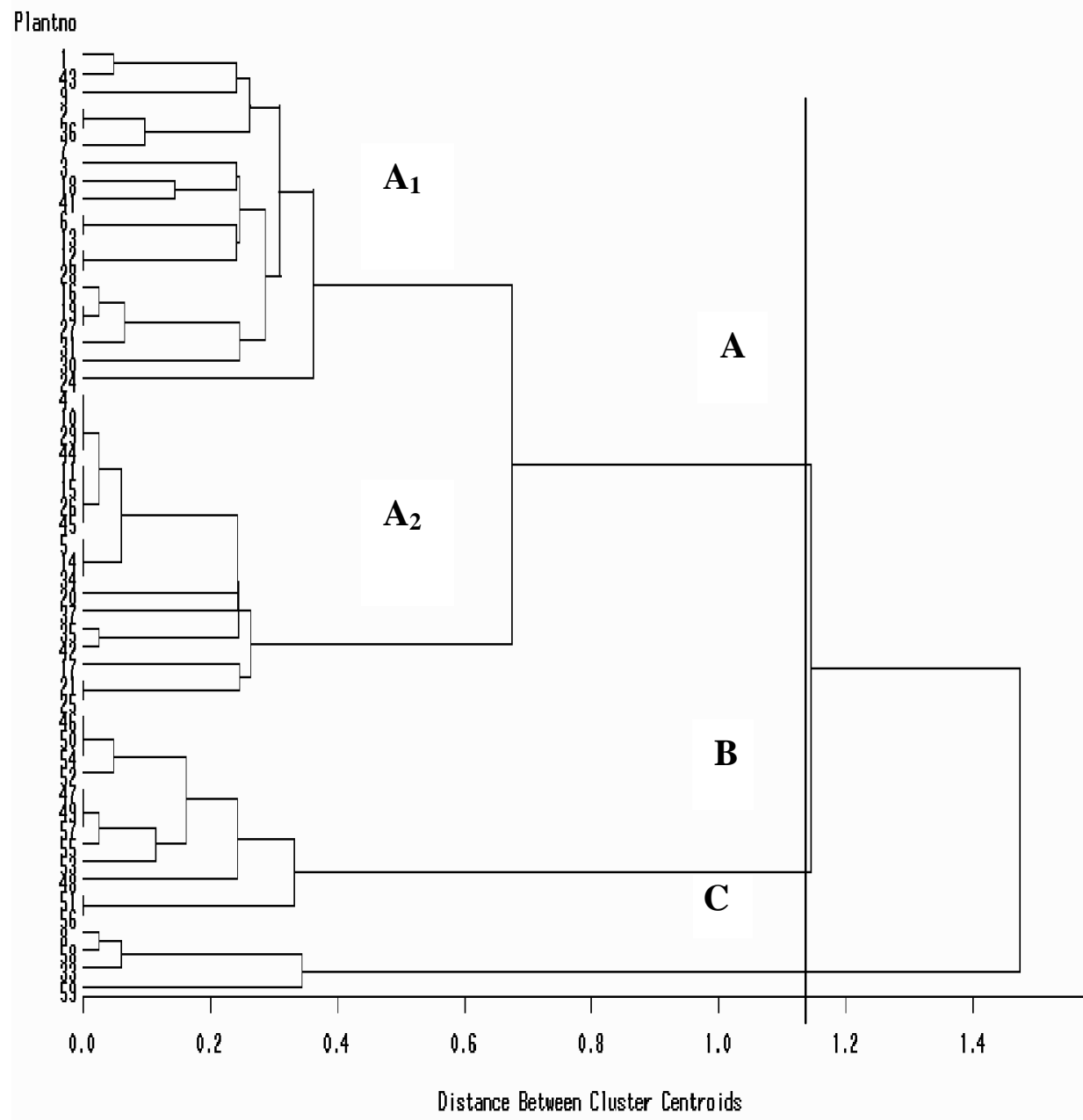

Fig. 2. Dendogram obtained from cluster analysis using eleven morphological characters.

[Note: A, B, and C represent C. sinuata, C. hookeri and $C$.

sinuata $\times C$. hookeri, respectively; $\mathrm{A}_{1}, \mathrm{~A}_{2}$ represent two morpho-types of $C$. sinuata]. 
Table 4. Comparison of three taxa based on selected characters.

\begin{tabular}{llll}
\hline Major characters & Taxon 1 & Taxon 2 & Taxon 3 \\
\hline Stem height $(\mathrm{cm})$ & $70-170(-200)$ & $100-360$ & $90-135$ \\
Stem diameter $(\mathrm{cm})$ & $1.5 \pm 0.180$ & $3.2 \pm 0.355$ & $1.5 \pm 0.212$ \\
Crown width $(\mathrm{cm})$ & $96 \pm 18$ & $170 \pm 25$ & $140 \pm 28$ \\
Crown height $(\mathrm{cm})$ & $24 \pm 9$ & $20 \pm 8$ & $22 \pm 3.5$ \\
No. of leaves & $26 \pm 6$ & $10 \pm 3$ & $22 \pm 4$ \\
Leaf type & Simple & Simply pinnate & Pinnatifid \\
Leaf shape & Linear & Lanceolate & Linear \\
Leaf base & Ending with sinuatae & Ending with pinnae Ending with deeply \\
& or entire margin & & lobed segments \\
Petiole length $(\mathrm{cm})$ & $3.8 \pm 0.330$ & $9.5 \pm 2.173$ & $4.5 \pm 0.212$ \\
Petiole scale $(\mathrm{cm})$ & $0.05-0.1$ x 0.3-0.4 & $0.1 \times 0.4-0.8$ & $0.1 \times 0.4-0.6$ \\
Petiole spines (density) & Absent or slight & Dense & Moderate \\
Petiole spines (cm) & $\leq 0.05$ & 0.1 & $0.05-0.1$ \\
Leaf length $(\mathrm{cm})$ & $55 \pm 10$ & $105 \pm 13$ & $74 \pm 15$ \\
Leaf width $(\mathrm{cm})$ & $2.8 \pm 0.44$ & $24.4 \pm 3.4$ & $4.4 \pm 0.70$ \\
Veins & Simple & Simple & Forked \\
No. of veins (pairs) & $3-5$ & $3-5$ & $6-10$ \\
No. of sori (pairs) & $1-3$ & $1-3$ & $6-8$ \\
Sori arrangement & On 1-3 lower pairs of On 1-3 lower pairs & At fork of veins \\
& veins & of veins & \\
\hline
\end{tabular}

Frequent hybridization has also been reported in Cyatheaceae (Conant, 1975, 1983; Tryon, 1976; Tryon and Tryon, 1982), prompting Conant and Cooper-Driver (1980) to propose a speciation mechanism based on the dispersal of second generation hybrids. In supporting this hypothesis, a new Cyathea srilankensis Ranil was described from Singharaja forest in close proximity to other Cyathea species (Ranil et al., 2009a), although its origin is yet to be resolved.

Table 5. Comparison of different reproductive events of parents and hybrid.

\begin{tabular}{llll}
\hline \multicolumn{1}{c}{ Event } & C. sinuata & C. hookeri & $\begin{array}{c}\text { C. sinuata } \times \text { C. } \\
\text { hookeri }\end{array}$ \\
\hline Time to spore germination (days) & $7-12$ & $7-12$ & $7-12$ \\
Germination of spore (\%) & $32 \pm 7.41$ & $13 \pm 3.92$ & $39 \pm 7.33$ \\
Time taken to develop heart shaped 27-30 & $27-30$ & $27-30$ \\
gametophyte (days) & & & \\
Width of gametophyte (mm) & $7-8$ & $6-8$ & $7-8$ \\
Initiation of antheridia (days) & $42-48$ & $42-48$ & $42-48$ \\
Initiation of archegonia (days) & $70-76$ & $70-76$ & $70-76$ \\
Male gametophytes (\%) & $68 \%$ & $70 \%$ & $68 \%$ \\
Female gametophytes (\%) & 0 & 0 & 0 \\
Bisexual gametophytes (\%) & $32 \%$ & $30 \%$ & $32 \%$ \\
Presence of spoprophytes (\%) & $27 \%$ & $6 \%$ & 0 \\
Time to first frond (days) & $150-170$ & $150-170$ & Not observed \\
\hline
\end{tabular}



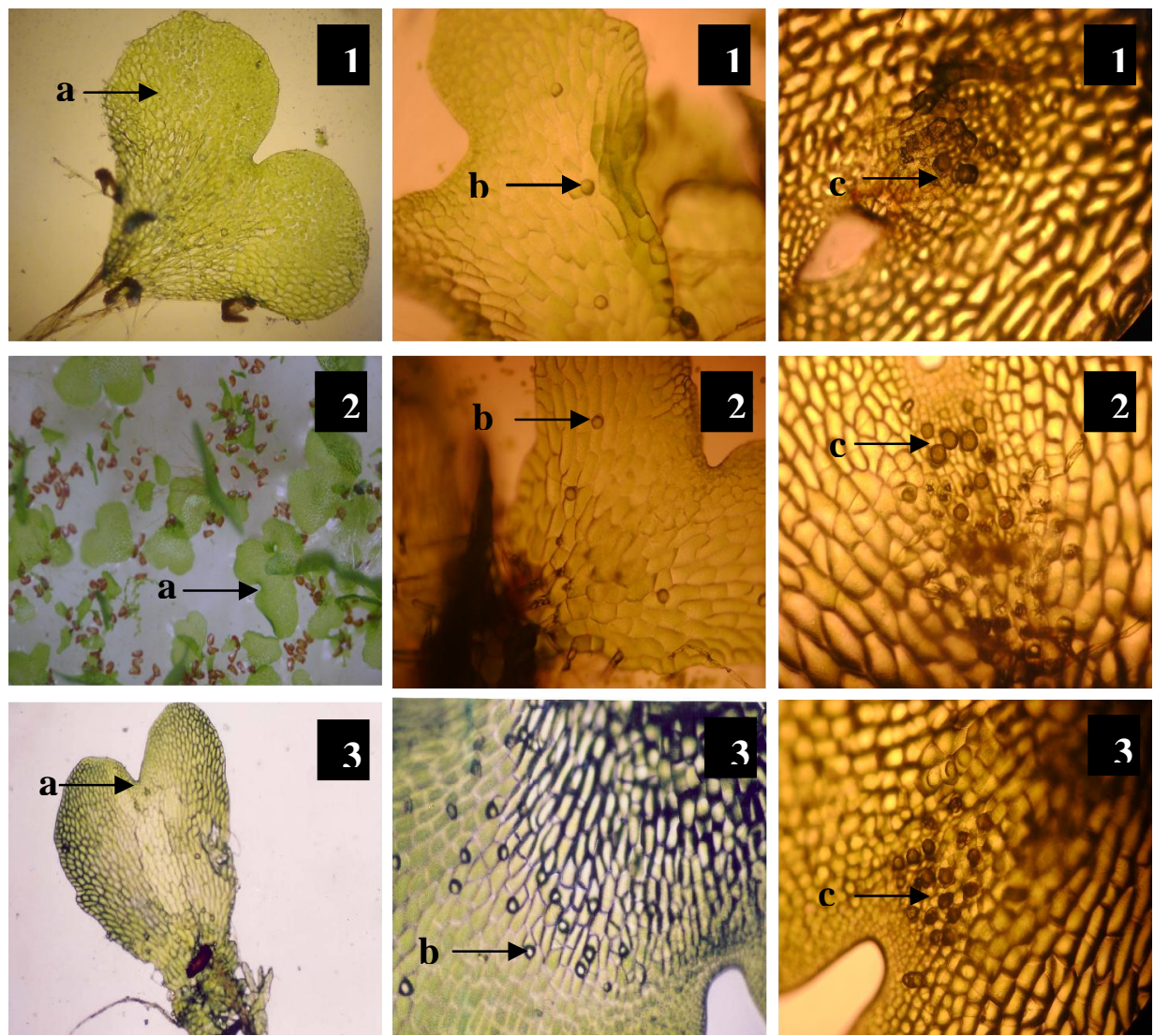

Plate 2. Different stages of gametophyte of Cyathea sinuata (1), $C$. sinuata $\times C$. hookeri (2) and $C$. hookeri (3). [Note: a, b and c represent heart shaped gametophytes 35 days after spore sowing (dass) (x 40), gametophyte with male sex organs at 42-48 dass (x 100), and gametophyte with female sex organs at 70-76 dass (x 100), respectively.]

However, many authors presented them as putative hybrids without giving details of parentage (Conant, 1975; Janssen and Rakotondrainibe, 2007). The recent work by Caluff (2002) and Caluff and Serrano (2002) has described four fertile Cyathea hybrids from Cuba with details. The present study also shows initial facts on hybridity which will be useful for future taxonomic work, while providing initial facts to study the speciation of the genus Cyathea in Sri Lanka.

\section{Cytological investigation}

The meiotic chromosome numbers of the two parents and the hybrid studied were similar $(n=69)$ (Plate 3). These findings are in agreement with previous cytological investigations of tree ferns although they did not specify the numbers (Manton and Sledge, 1954). According to Tryon and Tryon (1982), six genera of the Cyatheaceae are unusually consistent in their chromosome numbers $(\mathrm{n}=69,2 \mathrm{n}=138)$. Conant et al., (1996) and Love et al., (1977) suggested that this is the only family with near uniformity in chromosome number. 

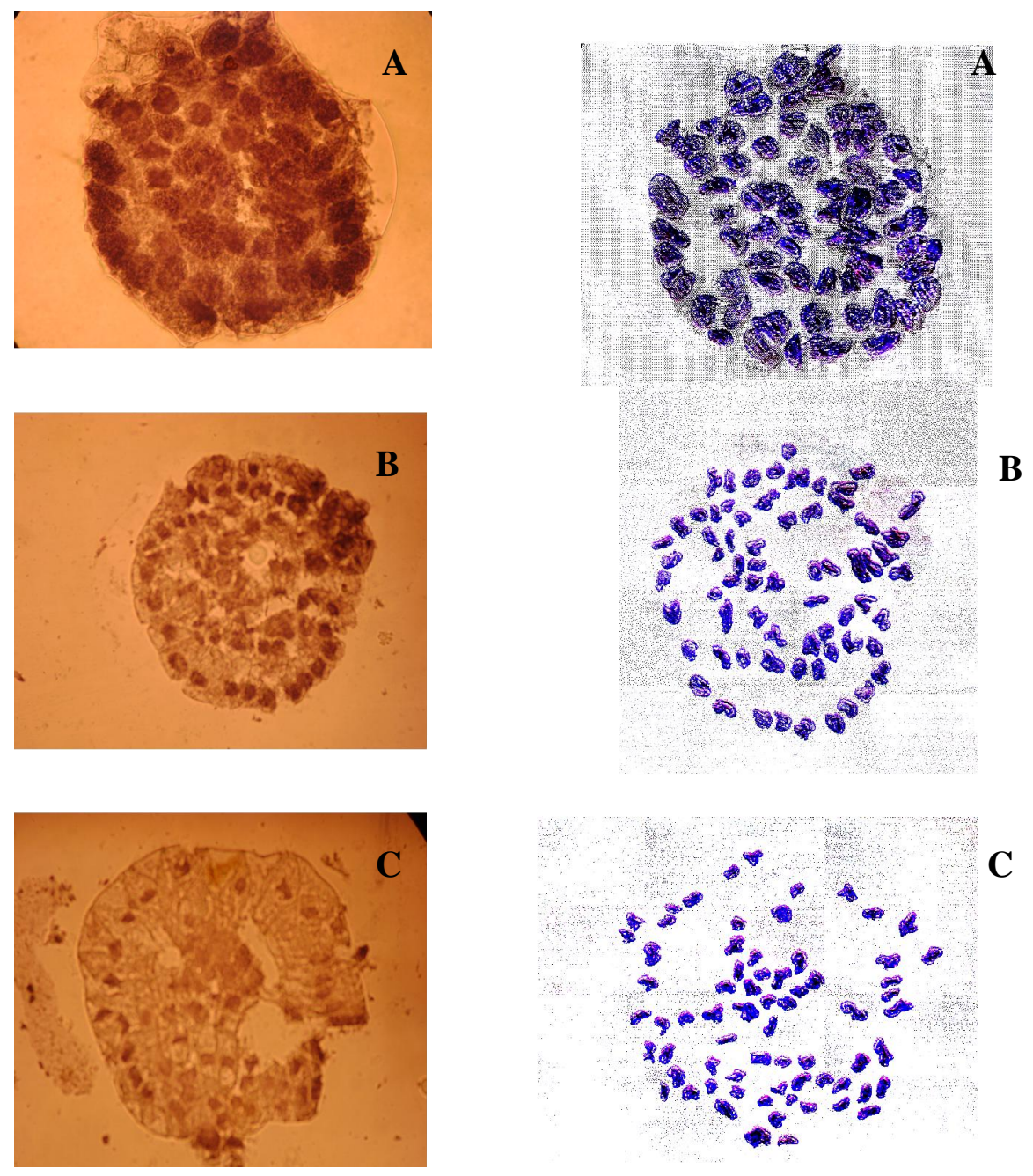

Plate 3. Chromosome count of Cyathea hookeri (A), C. sinuata (B) and C. sinuata $\times$ C. . hookeri $(\mathrm{C})(\mathrm{x}$ 1000).

Thus, chromosomal studies are not so useful to confirm taxonomic status of hybrids in the family Cyatheaceae. As Conant and Cooper-Driver (1980) suggested, since tree fern life cycles are long and experimental studies are difficult, morphological (Wagner, 1954; Tryon and Britton, 1966; Mulligan et al., 1972), and chemical analysis are well tested practical methods to use as a first approach to study of hybrids in the Cyatheaceae. While morphological features of hybrids usually tend to be intermediate, chemical components often are inherited additively from each parent (Conant and Cooper-Driver, 1980). The usual cytological methods for documenting hybridity have not been useful in this group due to high degrees of chromosome pairing (Conant and Cooper-Driver, 1980). However, after investigation of morphology, cytology and reproductive biology of both parents and presumed hybrid, it was tentatively named as Cyathea x sledgei Ranil (Ranil et al., 2009c). Genetic characterization with molecular techniques may also support in identification of hybrids which is now in progress for these three taxa. 


\section{CONCLUSIONS}

Based on the variation of morphological characters, three taxa were identified as $C$. sinuata and $C$. hooeki (parents) and the hybrid. Both parents and the hybrid are cytologically uniform $(\mathrm{n}=69)$. The hybrid is reproductively sterile.

\section{ACKNOWLEDGEMENTS}

The authors are indebted to the staff of the National Herbarium of Sri Lanka for their generous support. We also thank Mr. Tom Stuart, Coordinator of American Fern Society and Dr. W.P. de Winter, Wageningen University and Research Centre, Netherlands, for providing important information on the family Cyatheaceae. Authors are thankful to Dr. Monika Shaffer-Fehre, Kew Herbarium, UK for providing photocopies of original collections of the hybrid. We are grateful to Dr. Edward Salgado, Christian Brothers University, USA for providing information on venation study on ferns. Comments of Professor Chris Fraser-Jenkins is highly appreciated. Continuous support from Dr. Thomas Janssen, Department of Botany, Research Institute Senckenberg, Frankfurt, Germany is highly acknowledged. We are grateful to Professor V.S. Manikkum and Dr. V. Irudayaraj, St' Xavier's College, India for providing an excellent training on theory and practices of cytology of pteridophytes. Authors acknowledge the Forest Department of Sri Lanka for granting permission to carry out this study at Sinharaja and Kanneliya forests. The National Science Foundation of Sri Lanka is acknowledged for financing the research project (RG/06/EB/05).

\section{REFERENCES}

Bambaradeniya, C.N.B. (2006) (Ed.). Fauna of Sri Lanka: status of taxonomy, research and conservation. The World Conservation Union, Colombo, Sri Lanka.

Caluff, M.G. (2002). A note on Cuban tree fern hybrid Cyathea $\times$ calolepis (Cyatheaceae) and its parentage. Willdenowia 32: 311-318.

Caluff, M.G. and Serrano, G.S. (2002). Cuban novelties in the genus Alsophila (Cyatheaceae). Willdenowia 32: 303-309.

Conant, D.S. (1975). Hybrids in American Cyatheaceae. Rhodora 77: 441-455.

Conant, D.S. (1983). A revision of the genus Alsophila (Cyatheaceae) in the Americas. J. of the Arnold Arboretum 64:333-382.

Conant, D.S. (1990). Observation on the reproductive biology of Alsophila species and hybrids (Cyatheaceae). Annals of Missouri Bot. Garden. 77: 290-296.

Conant, D.S. and Cooper-Driver,G. (1980). Autogamous allohomorploidy in Alsophila and Nephelea (Cyatheaceae): a new hypothesis for speciation homoploid homosporous ferns. Amer. J. of Bot.y 67: 1269-1288.

Conant, D.S., Raubeson, L.A., Attwood, D.K., Perera, S., Zimmer, E.A., Sweere, J.A. and Stein, D.B. (1996). Phylogenetic and evolutionary implications of combined analysis of 
DNA and morphology in the Cyatheaceae. pp. 132-248. In: J.M. Camus, M. Gibby and R.J. Johns (Eds.): Pteridology in Perspective. Royal Botanical Gardens, Kew, United Kingdom. Dassanayake, M.D. and Fosberg, F.R. (1980-1991). A Revised Handbook to the Flora of Ceylon. Volumes I-VII. Amerind Publishing Company Private Limited, New Delhi, India.

Dassanayake, M.D., Fosberg, F.R. and Clayton, W.D. (1994-1995). A Revised Handbook to the Flora of Ceylon. Volumes VIII-IX. Oxford \& IBH Publishing Company Private Limited, New Delhi.

Dassanayake, M.D. and Clayton, W.D. (1996-1999). A Revised Handbook to the Flora of Ceylon. Volumes X-XIV. Oxford \& IBH Publishing Company Private Limited, New Delhi.

Holttum, R.E. (1965). Tree ferns of the genus Cyathea in Asia (excluding Malaysia). Kew Bulletin 19: 463-487.

Holttum, R.E. (1981). The tree ferns of Africa. Kew Bulletin 36: 463-483.

IUCN, (2007). The 2007 red list of threatened fauna and flora of Sri Lanka. IUCN, Colombo, Sri Lanka.

Janssen, T. and Rakotondrainibe, F. (2007). An update of the revision of Cyathea subgen. Alsophila sect. Gymnosphaera (Cyatheaceae) in Madagascar and the Comoros including a discussion of putative hybridization events. Adansonia 29(2): 195-213.

Janssen, T., Bystriakova, N., Rakotondrainibe, F., Coomes, D., Labat, J.N. and Schneider, H. (2008). Neoendemism in Madagascan tree ferns results from recent, coincident diversification bursts. Evol. 62: 1876-1889.

Kramer, K.U. (1990). Cyatheaceae. pp. 69-74. In: Kubitzki, K. (Ed.). The families and genera of vascular plants. Pteridophyes and Gymnosperm. Springer-Verlag, New York.

Love, A., Love, D. and Pichi-Sermolli, R. (1977). Cytotaxonomical Atlas of the pteridophyta. Cramer, Vaduz.

Manton, I. and Sledge, W.A. (1954). Observations on the cytological and taxonomy of the Pteridophyte flora of Ceylon. Philosophical Transactions of the Royal Soc.of Lon.. Series B, Biol. Sci. 238(654): 127-185.

MFE. (1999). Biodiversity conservation in Sri Lanka: A framework for action. Ministry of Forestry and Environment, Sampathpaya, Rajamalwatta Road, Battaramulla, Sri Lanka.

Mulligan, G.A., Cinq-Mars, L. and Cody, W.J. (1972). Natural interspecific hybridization between sexual and apogamous species of the beech fern genus Phegopteris Fee. Can. J. of Bot. 50: 1295-1300.

NSF. (2000). Natural resources of Sri Lanka 2000. The National Science Foundation of Sri Lanka, Colombo 7, Sri Lanka.

Philcox, D. (2006). Cyatheaceae pp. 48-55. In: Shaffer-fehre, M. (Ed.). A Revised Handbook of the Flora of Ceylon (Vol. XV). Pteridophyta (Ferns and Fern Allies). Amrind Publishing Company Private Limited, New Delhi, India. 
Ranil, R.H.G., Pushpakumara, D.K.N.G., Wijesundera, D.S.A., Dhanasekara, D.M.U.B. and Gunawardena, H.G. (2004). Species diversity of Pteridophyta in Kanneliya Man and Biosphere Reserve. The Sri Lanka Forester 27: 1-10.

Ranil, R.H.G., Pushpakumara, D.K.N.G., Wijesundara, D.S.A. and Dhanasekara, D.M.U.B. (2008). Domestication of Cyathea walkerae Hook. Sri Lankan J. of Agric.1 Sci. 45:47-58.

Ranil, R.H.G., Pushpakumara, D.K.N.G., Janssen, T., Wijesundara, D.S.A. and Dhanasekara, D.M.U.B. (2009a). Cyathea srilankensis Ranil: A new tree fern species from Sri Lanka. Ame. Fern J. Ame. Fern Soc., USA. (Accepted).

Ranil, R.H.G., Pushpakumara, D.K.N.G., Janssen, T. and Wijesundara, D.S.A. (2009b). Diversity and conservation priorities of scaly tree ferns of Sri Lanka. World Biodiversity Congress 2009, Chiang Mai, Thailand. 84 pp.

Ranil, R.H.G., Pushpakumara, D.K.N.G., Janssen, T., Fraser-Jenkins, C.R., Wijesundara, D.S.A. and Dhanasekara, D.M.U.B. (2009c). Cyathea $\times$ sledgei Ranil (Cyatheaceae): A natural hybrid from Sri Lanka. Fern Gazette, British Pterido. Soc., UK. (Accepted).

Strahler, A. and Strahler, A. (2005). Introducing physical geography. John Wiley and Sons, Inc. 269-308.

SAS. (1999). SAS institute Inc., Software/Release 8, Cary, NC, USA.

Sledge, W.A. (1982). An annotated checklist of the Pteridophyte of Ceylon. Bot. J. Linn. Soc. 84:1-30.

Tryon, R. and Britton, D.M. (1966). A study of variations in the cytotypes of Dryopteris spinulosa. Rhodora 68: 59-92.

Tryon, R. M. and Gastony, G.J. (1975). The biogeography of endemism in the Cyatheaceae. Fern Gazette 11:73-79.

Tryon, R. (1976). A Revision of the genus Cyathea. Contribution from Gray Herbarium of Harvard University 206: 19-98.

Tryon, R. M. and A. F. Tryon. (1982). Ferns and allies plants. Berlin: Springer-Verlag. 166175.

Wagner, W.H. (1954). Reticulate evolution in Appalachian Asplenium. Evolution 8:103-118. 
Annexure I. Assessment of Quantitative and qualitative characters of Cyathea sinuata, C. hookeri and suspected hybrid.

\begin{tabular}{|c|c|}
\hline Character & Description \\
\hline \multicolumn{2}{|l|}{ Ecology } \\
\hline 1. Habitat & $\begin{array}{l}\text { Terrestrial (1); lithophytic (2); epiphytes on buttresses } \\
\text { (3) }\end{array}$ \\
\hline \multicolumn{2}{|l|}{ Plant characters } \\
\hline 2. Plant habit & Growing as single plant (1); growing clumps (2) \\
\hline 3. Stem & Erect stem (1); slant stem (2); prostrate (3) \\
\hline 4. Branching & Unbranched (1); branched stem (2) \\
\hline 5. Stem height $(\mathrm{cm})$ & From substrate to growing point of plant \\
\hline 6. Stem diameter $(\mathrm{cm})^{*}$ & Measured at the mid height of the stem \\
\hline 7. Crown width $(\mathrm{cm})$ & Maximum width of the crown \\
\hline 8. Crown height $(\mathrm{cm})$ & $\begin{array}{l}\text { Distance between growing point and attachment point } \\
\text { of lowest leaf to the stem. }\end{array}$ \\
\hline 9. Crown shape & Conical shaped (1); flat (2); umbrella-shaped (3) \\
\hline \multicolumn{2}{|l|}{$\begin{array}{l}\text { Mature frond } \\
\text { characters }\end{array}$} \\
\hline $\begin{array}{l}\text { 10. Total number of } \\
\text { leaves }\end{array}$ & Total number of leaves per stem \\
\hline $\begin{array}{l}\text { 11. Number of mature } \\
\text { leaves per stem }\end{array}$ & Total number of spore-baring leaves per stem \\
\hline 12. Leaf orientation & Slant (1); parallel (2); drooping (3) \\
\hline 13. Leaf type* & Simple (1); pinnatifid (2); Simply pinnate (3) \\
\hline 14. Stalk length $(\mathrm{cm})$ & $\begin{array}{l}\text { Measured from the point of attachment of the petiole to } \\
\text { the main axis to the point of attachment to the leaf base }\end{array}$ \\
\hline 15. Leaf width (cm) & Maximum width of the leaf \\
\hline 16. Leaf length $(\mathrm{cm})$ & Base to the end of the tip \\
\hline 17. Leaf base & Oblique (1); obtuse (2); not as above (3) \\
\hline 18. Margin of base* & $\begin{array}{l}\text { Leaf ends up with entire margin (1); sinuate margin (2); } \\
\text { shallowly pinnatifid margin (3); deeply pinnatifid } \\
\text { margin (4); leaf end up with pinna (5) others. }\end{array}$ \\
\hline 19. Leaf margin* & $\begin{array}{l}\text { Outer margin grows towards midrib } 0-2 \mathrm{~mm} \text { distance } \\
\text { (1); } 2-4 \mathrm{~mm}(2) ; 4-15 \mathrm{~mm}(3) \text {. }\end{array}$ \\
\hline 20. Margin of leaf tip* & Acuminate (1); sinuate (2); crenate (3) \\
\hline 21. Veinlets* & Simple (1); forked $(1)$ \\
\hline $\begin{array}{l}\text { 22. No of veinlets in } \\
\text { single cluster* (pairs) }\end{array}$ & $\begin{array}{l}\text { Maximum number of veinlets observed in each cluster } \\
\text { recorded } 3 \mathrm{~cm} \text { away from either side of the widest width } \\
\text { of the leaf }\end{array}$ \\
\hline \multicolumn{2}{|l|}{ Sori } \\
\hline 23. Position of sori* & Beneath veinlets (1); on forked point (2) \\
\hline $\begin{array}{l}\text { 24. Average number of } \\
\text { sori in single cluster* } \\
\text { (pairs) }\end{array}$ & $\begin{array}{l}\text { Maximum number of sporangia of each cluster, } \\
\text { recorded } 5 \mathrm{~cm} \text { away from either side of the maximum } \\
\text { width of the leaf. }\end{array}$ \\
\hline 25. Sori arrangement* & Irregular (1), triangle (2), two rows (3) \\
\hline
\end{tabular}

